DOI: $\underline{10.35619 / \text { iiu.v2i13.389 }}$

Юрчук Олексій кандидат педагогічних наук, доцент кафедри дошкільної педагогіки і психології та спеціальної освіти імені проф. Т. І. Поніманської Рівненського державного гуманітарного університету, м. Рівне, Україна ORCID: 0000-0002-4764-1783 e-mail:abstractio@ukr.net

\title{
ФОРМУВАННЯ МОТИВАЦЇ̈ ДО ФІЗКУЛЬТУРНО-ОЗДОРОВЧОЇ РОБОТИ В ЗДО ЗДОБУВАЧІВ ВИЩОЇ ОСВІТИ СПЕЦІАЛЬНОСТІ 012 «ДОШКІЛЬНА ОСВІТА»
}

\begin{abstract}
Анотація. У статті розглядаються особливості формування мотивації до фізкультурно-оздоровчої роботи в закладах дошкільної освіти у майбутніх вихователів. Доведено необхідність забезпечення мотивації до означеного виду підготовки фахівців галузі дошкільної освіти. Обгрунтовано процес формування у майбутніх вихователів мотивації, вироблення інтересу до майбутньої професії, занять фізичною культурою, отримання нових знань, розуміння своєї ролі в збереженні здоров'я вихованців. Визначено пріоритетне джерело формування мотивації до фізкультурно-оздоровчої роботи у майбутніх вихователів (навчальні дисципліни, що відображають і теоретичні основи, і педагогічний досвід створення та реалізації фізкультурно-оздоровчих заходів). Розроблено спеціальний напрям діяльності здобувачів вищої освіти, який охоплює організацію спеціальних занять, навчальних завдань, загальноуніверситетських і міських заходів. З'ясовано, що практичне розв'язання проблеми зумовить у майбутніх вихователів формування допитливості, пізнавального інтересу й об'єктивне оцінювання власних можливостей, утвердить прагнення до саморозвитку та самовдосконалення під час проведення фізкультурно-оздоровчої роботи в закладі дошкільної освіти.
\end{abstract}

Ключові слова: майбутні вихователі, фізкультурно-оздоровча робота, мотивація, мотиваційна готовність.

Постановка проблеми. В усі часи показником цивілізованої держави була здорова нація. Головною проблемою для України, яка пов'язана $з$ іiі майбутнім, $\epsilon$ збереження і зміцнення здоров'я дітей. На сьогодні означена проблема стоїть надзвичайно гостро, оскільки динаміка здоров'я дітей та молоді нашої країни набула негативної тенденції - значно зростає кількість дітей із різними хронічними захворюваннями, порушеннями постави, що призводить до обмеження рухів. Від тривалості і ступеня їхньої вираженості 


\section{Інноватика у вихованні. Випуск 13.Том 2. 2021.}

залежить діапазон змін в організмі - від адаптаційно-фізіологічних до патологічних. Тому залучення дітей дошкільного віку до фізкультурнооздоровчої роботи є аспектом соціальної політики держави.

Стратегічні завдання збереження та зміцнення духовного, психічного та фізичного здоров'я дітей дошкільного віку, засвоєння ними цінностей фізичного виховання, виховання стійкого інтересу до рухової активності та потреби регламентовано законами України «Про вищу освіту» (2014), «Про освіту» (2017), «Про дошкільну освіту» (2017), «Про охорону дитинства» (2018), «Про фізичну культуру і спорт» (2013), Базовим компонентом дошкільної освіти (2012), Національною доктриною розвитку освіти України в XXI ст. (2002), Національною стратегією 3 оздоровчої рухової активності в Україні на період до 2025 року (2016), Національною стратегією розвитку освіти в Україні на період до 2021 року (2013).

У Національній стратегії з оздоровчої рухової активності в Україні на період до 2025 року «Рухова активність - здоровий спосіб життя - здорова нація» обгрунтовано ефективність використання рухової активності для підвищення функціональних та фізичних показників і профілактики низки захворювань у людей; визначено потребу модернізації в закладах освіти системи фізичного виховання, яке має бути органічно поєднано з іншими компонентами здорового способу життя.

3 огляду на те, що оптимальне фізичне навантаження дітей дошкільного віку в режимі дня забезпечують заклади дошкільної освіти, вирішення означеної проблеми уможливлюватиме формування у майбутніх вихователів мотивацію щодо організації та здійснення фізкультурно-оздоровчої роботи у вище названих закладах.

У контексті розкриття змісту останнього доречно наголосити, що майбутній вихователь повинен володіти знаннями та навичками, важливими для змістовної організації фізкультурно-оздоровчої діяльності, досягнення успіху в роботі, особистісного і професійного зростання, для розв'язання нових педагогічних завдань, підтримання та збереження здоров'я дітей, орієнтації їх на здоровий спосіб життя й активну рухову діяльність. Зміст формування мотивації майбутнього вихователя до фізкультурно-оздоровчої роботи зумовлений потребою підвищення професійного статусу та професійної самореалізації; виховання, збереження здоров'я дошкільників, орієнтації їх на здоровий спосіб життя.

На думку С. Микитюка (2012, с.178.), успішна професійна діяльність особистості залежить не лише від їі здібностей, а й від розвитку певного рівня мотивації до неї. Відтак, за умови наявності високого інтересу особистості до діяльності в дію вступає компенсаторний механізм, і недолік здібностей у результаті заповнюється розвитком мотиваційної сфери, що забезпечує досягнення успіху в діяльності.

Аналіз останніх досліджень 3 проблеми. Парадигма вивчення проблеми мотивації майбутніх вихователів у педагогічній науці представлена різними аспектами, як-от: визначення сутності й змісту 


\section{Інноватика у вихованні. Випуск 13.Том 2. 2021.}

мотиваційної готовності майбутніх педагогів до професійної діяльності (Х. Дмитерко-Карабін, Л. Іщенко, О. Коваленко, Т. Левченко, Б. Ломова, Т. Марєєва, А. Маркової, В. Семиченко, В. Шапар та ін.), формування мотивації майбутніх вихователів (Г. Бєленька, О. Богініч та ін.). Значний внесок у вивчення проблеми мотивації зробили зарубіжні і вітчизняні учені: М. Вебер, А. Маслоу, А. Маршалл, О. Павловська, В. Семиченко, А. Сміт, Туріщева та ін.

Мета статті - визначити основні шляхи формування мотивації до фізкультурно-оздоровчої роботи в ЗДО здобувачів вищої освіти спеціальності 012 «Дошкільна освіта».

Виклад основного матеріалу дослідження. У ході дослідження спостережено, що професорсько-викладацький склад закладів вищої освіти приділяе недостатньо уваги мотивації майбутніх вихователів до оздоровлення (це відображає тенденція до зниження фізичної активності останніх), що позначається не тільки на їхній фізичній працездатності, а й на стані здоров'я. Як наслідок, чим нижчою є мотивація майбутніх вихователів, тим гірше буде організовано фізично-оздоровчу діяльність дітей дошкільного віку. 3 огляду на тісний зв'язок мотивації із цілепокладанням мета оздоровлення, самостійно поставлена майбутніми вихователями перед собою, забезпечує відчутніше спонукання, викликає більшу активність, створює позитивний настрій щодо іï досягнення та утримується довше. У процесі професійного саморозвитку в аспекті фізкультурно-оздоровчої роботи механізми мотиваційної сфери стимулюють майбутніх вихователів до досягнення успіху, формування впевненості у собі, задоволеності діяльністю.

Як слушно окреслила I. Мельничук (2010, с.211), «проблема мотивації і мотивів діяльності визначається в наукових колах однією 3 основоположних, оскільки розкриває зміст спонукальних механізмів активності людини».

Загалом мотиваційна готовність майбутніх вихователів до фізкультурно-оздоровчої діяльності охоплює особистісну мотивацію (потребу отримання задоволення від фізкультурно-оздоровчої роботи 3 дошкільниками); професійно-пізнавальні мотиви, зорієнтовані на набуття додаткових компетентностей щодо здійснення рухового режиму в ЗДО; динамічний стереотип діяльності й поведінки майбутніх вихователів щодо здорового способу життя, який визначає дбайливе ставлення до власного здоров'я та здоров'я довколишніх, а саме - дітей дошкільного віку; прагнення до більш повного виявлення та використання особистісних можливостей у професійній діяльності й здійснення фізкультурнооздоровчої роботи загалом і в ЗДО зокрема; мотиви самоосвіти та професійного самовдосконалення.

У роботі мотивацією майбутнього вихователя до фізкультурнооздоровчої роботи в ЗДО вважаємо сукупність мотивів (навчальнопізнавальних, професійних, соціальних, творчих), що зумовлюють 


\section{Інноватика у вихованні. Випуск 13.Том 2. 2021.}

формування у здобувачів позитивного ставлення до фізкультурнооздоровчої та здоров'язбережувальної діяльності.

Погоджуємось 3 твердженням О. Богініч, що на посилення мотиваційного компоненту впливає ступінь сформованості оздоровчосвітоглядних позицій у викладача та студентів і систематичність виконання завдань оздоровчого спрямування (Богініч).

Формування у майбутніх вихователів мотивації, тобто вироблення інтересу до майбутньої професії, занять фізичною культурою, отримання нових знань, розуміння своєї ролі у збереженні здоров'я вихованців, можна забезпечити шляхом розроблення спеціального напряму діяльності студентів, який охоплює організацію спеціальних занять, навчальних завдань, загальноуніверситетських i міських заходів. Практичне розв'язання проблеми формування у майбутніх вхователів мотивації до професійної діяльності, інтересу до фізкультурно-оздоровчої діяльності в ЗДО передбачає тривалість упродовж усього періоду навчання у закладі вищої освіти. Такий підхід зумовить у майбутніх вихователів формування допитливості, пізнавального інтересу й об'єктивне оцінювання власних можливостей, утвердить прагнення до саморозвитку та самовдосконалення під час проведення фізкультурно-оздоровчої роботи в ЗДО.

В експериментальному дослідженні було задіяно 52 здобувачі першого освітнього ступеня «бакалавр» спеціальності «Дошкільна освіта».

Для дослідження мотиваційної готовності майбутніх вихователів до фізкультурно-оздоровчої роботи використано методику «Мотиви вибору професії» (В. Семиченко) та «Мотивація професійної діяльності» (К. Замфір (модифікація А. Реана).

Відтак, на основі аналізу отриманих унаслідок використання методик «Мотиви вибору професії» (В. Семиченко) та «Мотивація професійної діяльності» (К. Замфір (модифікація А. Реана) даних визначено показник внутрішньої мотивації на низькому рівні у 40,4\% здобувачів; на середньому - у 44,2\%; на високому - у 15,4\% здобувачів. Низький рівень зовнішньої позитивної мотивації простежено у 42,3\% респондентів; середній у 48,1\% і високий лише у 9,6\% респондентів. Низький рівень зовнішньої негативної мотивації притаманний 17,3\% опитаних; середній $53,8 \%$; високий - $28,9 \%$ респондентам.

Аналіз результатів дослідження дає підстави стверджувати про сформованість мотивів вибору професії у майбутніх вихователів переважно на середньому рівні $(48,7 \%)$. Припускаємо, що більшість опитаних здобувачів керуються соціально-значущими мотивами (мотиви отримання достатньої заробітної платні, прагнення до кар'єрного зростання тощо). Утім, очевидно, що частина майбутніх вихователів $(33,3 \%)$ мають недостатній рівень сформованості мотивів вибору професії 3 огляду на домінування у них зовнішних негативних мотивів.

Лише невелика частина опитаних, а саме 18,0 \% демонструє високий рівень сформованості мотивів вибору професії, яким властива характерна 
орієнтація і на внутрішні, і зовнішні позитивні мотиви (задоволення від роботи, бажання бути корисним людям тощо).

Наступний блок дослідження відзначався спрямованістю з'ясування ставлення студентів до занять з фізичного виховання, оскільки організація i здійснення фізкультурно-оздоровчої роботи передусім передбачає належний фізичний розвиток майбутнього вихователя та виконання ним необхідних рухів. Вихователь, який сам не є фізично активним, не здатен виховувати й розвивати в дошкільників любов та інтерес до рухової активності, до фізичного виховання зокрема. Також блок було зорієнтовано на виявлення знань студентів про організацію фізкультурнооздоровчої роботи і їі оптимізацію.

Таким чином, аналіз результатів дослідження за методиками «Мотиви вибору професії» В. А. Семиченко та «Мотивація професійної діяльності (К. Замфір (модифікація А. Реана)», а також проведеного анкетування здобувачів дав змогу визначити узагальнений рівень сформованості показників мотиваційної готовності майбутніх вихователів до фізкультурно-оздоровчої роботи. Так, низький рівень мотиваційної готовності притаманний 40,4\% здобувачів, середній рівень - 38,5\% досліджуваних, високий рівень $-21,1 \%$ опитаних.

Отже, отримано високий відсоток негативної мотивації у більшості майбутніх вихователів, значна частина 3 яких продемонструвала нерозвинену внутрішню мотивацію та переважання зовнішніх стимулів. Причина таких результатів криється у студентській невпевненості щодо рівня власних знань і вмінь здійснювати фізкультурно-оздоровчу роботу, а також пов'язана зі страхом невдач і осуду однокурсників, а згодом колег. На наше переконання, невпевненість у власних силах також пов'язана і з недостатніми знаннями з організації фізкультурно-оздоровчої діяльності в ЗДО.

Для вирішення завдань мотиваційної готовності майбутніх фахівців дошкільної освіти було використано такий арсенал активних методів навчання, як створення проблемних ситуацій, проведення бесіди, демонстрацію наочних посібників, звернення до власного досвіду, залучення професійно-просвітницьких технологій тощо. 3 огляду на те, що кожне заняття мало на меті зосередити увагу здобувачів на поставленій проблемі й викликати інтерес до ï вирішення, майбутні вихователі й викладачі брали активну участь у вирішенні таких завдань і обговоренні професійних проблем.

Пріоритетним джерелом формування мотивації до фізкультурнооздоровчої роботи у майбутніх вихователів $є$ навчальні дисципліни, що відображають і теоретичні основи, і педагогічний досвід створення та реалізації рухового режиму. Ще одним джерелом слугували знання про: 1) систему підготовки; 2) принципи підготовки (принцип міжпредметних зв'зків, принцип науковості тощо); 3) організаційні форми та методи професійної підготовки майбутніх вихователів. 


\section{Інноватика у вихованні. Випуск 13.Том 2. 2021.}

На основі аналізу навчальних планів підготовки фахівців спеціальності «Дошкільна освіта» констатуємо, що значну роль у формуванні мотивації та орієнтації майбутніх вихователів до фізкультурно-оздоровчої роботи в ЗДО відіграють такі навчальні дисципліни:

- на I курсі - «Вступ до спеціальності», «Вікова фізіологія та валеологія»;

- на II курсі з продовженням на III курсі - «Психологія дитяча», «Педагогіка дошкільна»;

- на III курсі - «Теорія та методика фізичного виховання та валеологічної освіти».

У ході визначення навчальних дисциплін, звертали увагу саме на ті, що на нашу думку, найбільш максимально сприяють процесу підготовки майбутніх вихователів до фізкультурно-оздоровчої роботи в ЗДО. Ті дисципліни, про які не йдеться (педагогіка загальна, теорія та методика співпраці з родинами, педагогіка раннього дитинства, організаційна та методична робота в дошкільному закладі, фізичне виховання та інші), теж реалізовували в діяльності викладача. Вивчення студентом вищеперерахованих навчальних дисциплін передбачає набуття ним знань, що уможливлюють створення в його уяві образу професії, що охоплює: цілі та завдання професійної діяльності, знання, практичні уміння та навички, необхідні майбутньому вихователеві для організації фізкультурно-оздоровчої роботи в ЗДО; особистісні якості майбутнього фахівця дошкільної освіти; методи та технології роботи 3 дітьми дошкільного віку.

Програма з формування мотивації до фізкультурно-оздоровчої роботи майбутніх вихователів передбачала:

відвідування міських фізкультурно-спортивних заходів для дошкільнят («Шаховий турнір», Усеукраїнські змагання з малючкового плавання «Діти води», художня гімнастика, Рівненська міська олімпіада для дошкільнят, комплексна спартакіада серед дошкільних навчальних закладів міста Рівне та змагання «Веселі старти дошкільнят», Усеукраїнські спортивні заходи «Спортивна зима» серед ЗДО);

участь у звітних наукових конференціях викладачів, співробітників, аспірантів, докторантів i студентів, у студентських наукових конференціях, семінарах, присвячених проблемам фізичному вихованню в дошкільній освіті, на яких розкривали різноманітні концепції проблеми фізичного виховання дітей, представляли результати роботи із джерелами, підбивали підсумки самостійної роботи студентів;

участь у групових дискусіях, присвячених обговоренню конкретних питань з проблеми фізичного виховання;

ділові ігри, у ході яких відтворювали предметне середовище професійної діяльності, моделювали відповідну систему стосунків, відпрацьовували професійні навички майбутнього фахівця «Дошкільної освіти», формували інтерес до занять. 


\section{Інноватика у вихованні. Випуск 13.Том 2. 2021.}

Позитивно позначалися на залученні майбутніх вихователів до рухової активності та здорового способу життя такі загальнофакультетські, загальноунверситетські та міські масові фізкультурно-спортивні заходи:

туристичні походи, під час яких студенти навчалися використовувати прийоми орієнтування у навколишньому середовищі й активних способів пересування (такі знання та прикладні навички у майбутньому полегшать планування туристичних походів 3 дітьми);

масові фізкультурно-спортивні заходи (легкоатлетичний крос «Олімпійська миля», «Тиждень здоров'я», «День фізичної культури та спорту»), змагання (із баскетболу, волейболу «М'яч над сіткою», плавання), які не тільки сприяють підвищенню рухової активності майбутніх вихователів, а й формують потребу систематичних самостійних занять фізичними вправами;

залучення студентів до здорового способу життя шляхом організації та участі у фізкультурно-спортивних і фізкультурно-оздоровчих заходах закладу вищої освіти чи міста.

У дослідженні великого значення надавали спортивно-оздоровчим секціям. Усіх здобувачів, які брали участь в експерименті, було зобов'язано записатися на різних видів спортивних секцій - з волейболу, баскетболу, настільного тенісу, загальної фізичної підготовки. Найбільш популярними серед майбутніх вихователів виявилися заняття фітнесом, ритмікою, аеробікою. Для підвищення мотивації до активної рухової діяльності вибір засобів фізичного виховання був абсолютно самостійним і не обмеженим обов'язковим переліком. Під час відвідування спортивних секцій майбутні вихователі дотримувалися низки нижчевикладених умов:

здорове харчування;

урахування стану фізичного здоров'я та індивідуальних можливостей організму;

спрямованість на результат;

фіксування отриманих результатів у щоденник здоров'я;

відвідування консультативної секції.

Слід наголосити, що консультативну секцію було створено при кафедрі дошкільної педагогіки і психології спеціальної освіти імені проф. Т. І. Поніманської. Мета роботи секції полягала у наданні консультативної допомоги та підтримки майбутнім вихователям 3 питань здорового способу життя. Секційні засідання відбувалися двічі на місяць i на вимогу студентів.

Дослідження також передбачало участь майбутніх вихователів у волонтерській діяльності у сфері фізичного виховання та спорту міста. Так, здобувачів було залучено до волонтерської діяльності Рівненського обласного центру фізичного здоров'я населення «Спорт для всіх», для чого вони заповнювали «Анкету волонтера». Участь у волонтерській роботі сприяє отриманню майбутніми вихователями корисних знань про здоровий спосіб життя; урізноманітненню студентського життя; 


\section{Інноватика у вихованні. Випуск 13.Том 2. 2021.}

отриманню досвіду з організації масових спортивно-оздоровчих заходів; отриманню знань для надання консультацій щодо самостійних занять фізичними вправами.

Для обгрунтування ефективності заходів педагогічного впливу в рамках упровадження програми формування мотивації до фізкультурнооздоровчої роботи в ЗДО майбутніх вихователів було застосовано параметричний метод $t$-Стьюдента для залежних вибірок (Paired Samples T-Test) (Бююль, Цьофель, 2002). Додатково, для визначення ступеня відповідності емпіричного розподілу показників вираженості особистісних характеристик досліджуваних і нормального, було залучено метод Колмогорова-Смирнова (One-Sample Kolmogorov-Smirnov Test) (Бююль, Цьофель, 2002).

Так, достовірний характер зростання середніх значень вираженості особистісних характеристик у досліджуваних було підтверджено щодо: внутрішніх індивідуально значущих мотивів (за В. Семиченко) $(p \leq 0,001)$, зовнішньої позитивної мотивації (за А. Реаном) $(p \leq 0,001)$, внутрішніх позитивних мотивів (за В. Семиченко) $(p \leq 0,001)$, внутрішньої мотивації (за А. Реаном) $(p \leq 0,01)$ і внутрішніх соціально значущих мотивів (за В. Семиченко) $(p \leq 0,05)$. Достовірний характер зниження середніх значень вираженості особистісних характеристик у досліджуваних також було підтверджено щодо зовнішньої негативної мотивації (за А. Реаном) $(p \leq 0,001)$ і зовнішніх негативних мотивів (за В. Семиченко) $(p \leq 0,05)$.

Після підсумкового контролю зафіксовано зростання показників внутрішніх індивідуально значущих мотивів (за В. Семиченко) від 14,85 до 16,67 балів. Наголосимо на позитивній динаміці сформованості готовності майбутніх вихователів до фізкультурно-оздоровчої роботи в ЗДО за показниками зовнішньої позитивної мотивації та зовнішньої негативної мотивації (за А. Реаном). Так, з'ясовано підвищення показників зовнішньої позитивної мотивації у майбутніх вихователів із 2,942 до 3,106 балів, а також зменшення зовнішньої негативної мотивації із 2,865 до 2,577 балів.

Також, як позитив відзначимо збільшення середніх значень показників внутрішніх позитивних із 12,06 до 12,69 та зменшення зовнішніх негативних мотивів (за В. Семиченко) $з$ 11,79 до 11,60. Такі результати підтверджують ефективність розробленої програми у формуванні мотивації до фізкультурно-оздоровчої роботи майбутніх вихователів.

У ході дослідження встановлено, що у майбутніх вихователів відбулося зростання середніх значень внутрішніх соціально значущих мотивів (за В. Семиченко) із 13,50 до 13,88 балів. 
Інноватика у вихованні. Випуск 13.Том 2. 2021.

Таблиця 1

Відмінності у середніх значеннях вираженості особистісних характеристик досліджуваних

\begin{tabular}{|c|c|c|c|c|c|c|c|}
\hline \multirow[b]{2}{*}{$\begin{array}{c}\text { Етап } \\
\text { діагностичного } \\
\text { контролю }\end{array}$} & \multicolumn{7}{|c|}{$\begin{array}{c}\text { Середні значення вираженості особистісних } \\
\text { характеристик досліджуваних }\end{array}$} \\
\hline & 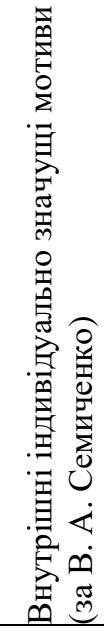 & 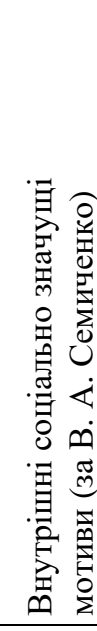 & 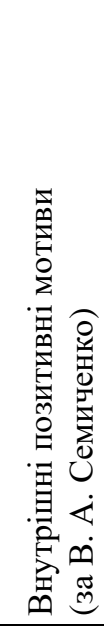 & 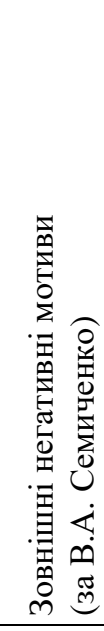 & 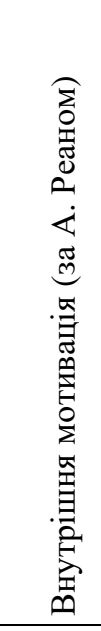 & 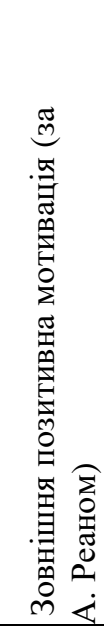 & 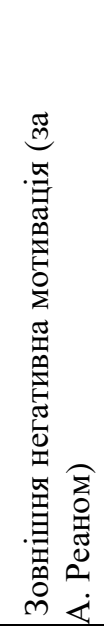 \\
\hline Ввідний & 14,85 & 13,50 & 12,06 & 11,79 & 2,962 & 2,942 & 2,865 \\
\hline Контрольний & 16,67 & 13,88 & 12,69 & 11,60 & 3,115 & 3,106 & 2,577 \\
\hline $\begin{array}{l}\text { рівень } \\
\text { статистичної } \\
\text { значущості }\end{array}$ & 0,000 & 0,020 & 0,001 & 0,024 & 0,003 & 0,000 & 0,000 \\
\hline
\end{tabular}

Висновки і перспективи подальших розвідок. Отже, розроблена та впроваджена методика сприяє формуванню мотивації майбутніх вихователів до фізкультурно-оздоровчої роботи в ЗДО, стимулює здобувачів до кращого розуміння професійної ролі та організації фізкультурно-оздоровчої роботи в ЗДО, поглибленню знань і вмінь. Перспективи подальших наукових розвідок вбачаємо у досліджені особливостей формування мотивації до фізкультурно-оздоровчої роботи в закладах дошкільної освіти у майбутніх вчителів першого освітнього ступеня «бакалавр» інших спеціальностей.

\section{СПИСОК ВИКОРИСТАНИХ ДЖЕРЕЛ}

Микитюк, С. (2012). Ресурсний підхід до професійної підготовки майбутнього вчителя: монографія. Харків: Монограф. 342 с. 


\title{
Інноватика у вихованні. Випуск 13.Том 2. 2021.
}

Мельничук, I. (2010). Теорія і практика професійної підготовки майбутніх соціальних прациівників засобами інтерактивних технологій: монографія. Тернопіль. 326 с.

Богініч, О. Концептуальні основи професійної підготовки майбутніх вихователів до фізкультурно-оздоровчої діяльності. URL: http://www.ird. npu. edu.ua. [Дата звернення 3.05.21].

Бююль А. та Цёфель П. (2002). SPSS: искусство обработки информации: анализ статистических данных и восстановление скрытых закономерностей: пер. с нем. / А. Бююль. СПб.: ООО «ДиаСофтЮГ», 2002. $608 \mathrm{c}$.

\section{REFERENCES}

Mykytiuk, S. (2012). Resursnyi pidkhid do profesiinoi pidhotovky maibutnoho vchytelia: monohrafiia [Resource approach to the training of future teachers: a monograph]. Kh.: monohraf. 342 s.

Melnychuk, I. (2010). Teoriia $i$ praktyka profesiinoi pidhotovky maibutnikh sotsialnykh pratsivnykiv zasobamy interaktyvnykh tekhnolohii : monohrafiia [Theory and practice of professional training of future social workers by means of interactive technologies: monograph]. Ter. $326 \mathrm{~s}$.

Bohinich, O. Kontseptualni osnovy profesiinoi pidhotovky maibutnikh vykhovateliv do fizkulturno-ozdorovchoi diialnosti [Conceptual bases of professional training of future educators for physical culture and healthimproving activity]. URL: http://www.ird. npu. edu.ua. [Data zvernennia 03.05.21].

Biuiul, A. \& Tsëfel, P. (2002). SPSS: iskusstvo obrabotki informatsii: analiz statisticheskikh dannykh $i$ vosstanovleniye skrytykh zakonomernostei [SPSS: The Art of Information Processing: Analyzing Statistical Data and Recovering Hidden Patterns] : per. s nem. / A. Biuiul. SPb.: OOO "DyaSoftIuH". $608 \mathrm{~s}$.

\section{FORMATION OF MOTIVATION FOR PHYSICAL AND HEALTH WORK IN PRESCHOOL EDUCATION INSTITUTIONS FOR STUDENTS OF HIGHER EDUCATION SPECIALITY 012 "PRESCHOOL EDUCATION"}

\author{
Oleksii Yurchuk \\ Candidate of Pedagogical Sciences, \\ Associate Professor at the Professor T.Ponimanska Department of \\ Preschool Pedagogy and Psychology and Special Education \\ Rivne State University for the Humanities, \\ Rivne, Ukraine \\ ORCID: 0000-0002-4764-1783 \\ e-mail: abstractio@ukr.net
}

Abstract. The article examines the peculiarities of the formation of motivation for physical culture and health-improving work in preschool 


\section{Інноватика у вихованні. Випуск 13.Том 2. 2021.}

educational institutions for future educators. The necessity of providing motivation for the specified type of training of specialists in the field of preschool education has been proved. The process of formation of motivation in future educators, development of interest in the future profession, physical education, acquisition of new knowledge, understanding of their role in maintaining the health of students was substantiated in the article. The priority source of formation of motivation for physical culture and health-improving work at future educators was defined (the disciplines reflecting both theoretical bases, and pedagogical experience of creation and realization of physical culture and health-improving actions). The main source of motivation in the work of the future educator towards physical exercise and health work in preschool education institutions was considered as a set of motives (educational, cognitive, professional, social, creative), which determine the formation of a positive attitude to physical exercise and health activities.

A special direction of activity of students of higher education has been developed, which includes the organization of special classes, educational tasks, university and city events. It was found that the practical solution of the problem will lead the future educators to the formation of curiosity, cognitive interest and objective assessment of their own abilities; it will strengthen the desire for self-development and self-improvement during physical exercise and health work in preschool education.

Keywords: future educators, physical culture and health-improving work, motivation, motivational readiness.

Стаття надійшла до редакиії 07. 05. 2021 р. 